Article

\title{
$\beta$-Adrenoceptors Trigger Melatonin Synthesis in Phagocytes
}

\author{
Marco A. Pires-Lapa ${ }^{1}$, Claudia E. Carvalho-Sousa ${ }^{1}$, Erika Cecon ${ }^{1}$ (D), Pedro A. Fernandes ${ }^{2}$ \\ and Regina P. Markus 1,* (D) \\ 1 Laboratory of Chronopharmacology, Deartment of Physiology, Institute of Bioscience, \\ University of São Paulo, 05508-900 São Paulo, Brazil; marco_lapa_bio@yahoo.com.br (M.A.P.-L.); \\ claudiabaete@gmail.com (C.E.C.-S.); kika.cecon@gmail.com (E.C.) \\ 2 Laboratory of Neuroimmunoendocrinology, Department of Physiology, Institute of Bioscience, \\ University of São Paulo, 05508-900 São Paulo, Brazil; pacmf@usp.br \\ * Correspondence: rpmarkus@usp.br; Tel.: +55-11-3091-7612
}

Received: 1 June 2018; Accepted: 16 July 2018; Published: 26 July 2018

\begin{abstract}
Melatonin (5-methoxy- $N$-acetylserotonin), the pineal hormone, is also synthesized by immune-competent cells. The pineal hormone signals darkness, while melatonin synthesized on demand by activated macrophages at any hour of the day acts locally, favoring regulatory/tolerant phenotypes. Activation of $\beta$-adrenoceptors in pinealocytes is the main route for triggering melatonin synthesis. However, despite the well-known role of $\beta$-adrenoceptors in the resolution macrophage phenotype (M2), and the relevance of macrophage synthesized melatonin in facilitating phagocytic activity, there is no information regarding whether activation of $\beta$-adrenoceptors would induce melatonin synthesis by monocytes. Here we show that catecholamines stimulate melatonin synthesis in bone marrow-derived dendritic cells and RAW 264.7 macrophages. Activation of $\beta$-adrenoceptors promotes the synthesis of melatonin by stimulating cyclic AMP/protein kinase A (PKA) pathway and by activating the nuclear translocation of NF- $\mathrm{kB}$. Considering the great number of macrophages around sympathetic nerve terminals, and the relevance of this system for maintaining macrophages in stages compatible to low-grade inflammation, our data open the possibility that extra-pineal melatonin acts as an autocrine/paracrine signal in macrophages under resolution or tolerant phenotypes.
\end{abstract}

Keywords: melatonin; macrophages; beta-adrenergic receptors; immune-pineal axis; nuclear factor kappa B (NF-kB); extra-pineal melatonin synthesis

\section{Introduction}

Melatonin acts as a buffer of the immune system, stimulating immune responses under immunosuppressed conditions, and repressing innate and adaptive immune responses in physiological conditions [1]. In control conditions, nocturnal melatonin rise impairs leukocyte migration through the endothelial layer, controlling the entry of defense cells in healthy tissues [2]. During the mounting of an inflammatory response, pro-inflammatory cytokines and pathogen- or danger-associated molecular patterns (PAMPs and DAMPs) reduce or even suppress pineal gland melatonin synthesis [3,4], favoring the migration of leukocytes to the injured tissue. The duration of PAMPs/DAMPs inhibition of pineal melatonin synthesis depends on the nature of the stimuli [5-8]. The incubation of human colostrum monocytes with Escherichia coli induces melatonin synthesis which stops after all bacteria are killed, whereas in the same cell type the melatonin synthesis induced by the PAMP derived from the fungi membrane, zymosan, lasts throughout the experimental observation $[7,8]$. Both exogenous melatonin [9-12] and melatonin synthesized by activated immunocompetent cells regulate 
the inflammatory response [13-18]. In resolution macrophages (M2), melatonin induces the synthesis of membrane proteins, such as dectin-1 [6] which increases phagocytosis [5,6], and arginase I which deviates arginine conversion from nitric oxide into ornithine and urea [19]. These are transient changes, and the return to basal conditions results in the restoration of daily pineal melatonin rhythm and reduction of melatonin synthesis by macrophages. Such switching of melatonin sources, from pineal-to-immune-back-to-pineal, was defined as the immune-pineal axis, which provides a theoretical basis for the chronobiotic and protective functions of melatonin [3].

The daily rhythm of pineal melatonin synthesis relies on the stimulation of pinealocytes $\beta$-adrenoceptors which trigger the transcription of the arylalkylamine- $N$-acetyltransferase (Aanat) gene and the activation of the enzyme [20]. Both effects are mediated by cyclic AMP-induced protein kinase A (PKA) activation. The suppression of Aanat transcription induced by PAMPs and DAMPs is mediated by the nuclear translocation of the nuclear factor kappa B (NF-KB) [4], which is the key element for switching melatonin synthesis from pineal gland to immune-competent cells. Indeed, the dimer p50/p50 is responsible for suppressing Aanat transcription, while dimers containing RelA or c-Rel lead to the transcription of this gene [21]. Accordingly, p50/RelA activation during the pro-inflammatory phase enhances the transcription of Rel, the gene that encodes c-Rel, which in its turn increases the transcription of proteins involved in the regulatory phase [22]. As such, the dimers of NF- $\mathrm{kB}$ coordinate the site of melatonin synthesis at distinct phases of the immune-inflammatory response.

Given that pineal melatonin is a temporal marker, the on/off switch of biosynthetic enzymes is crucial. As mentioned above, upon activation, $\beta$-adrenoceptors located in pinealocytes trigger the cAMP/PKA/CREB pathway and lead to Aanat transcription. AANAT converts serotonin into $\mathrm{N}$-acetylserotonin, which is then methylated by $\mathrm{N}$-acetylserotonin methyltransferase (ASMT) originating melatonin (5-methoxy- $N$-acetylserotonin). Once translated, AANAT is rapidly ubiquitinated and degraded by the proteasome $[20,23]$. The stabilization of the enzyme by the chaperone 14-3-3 requires the phosphorylation of AANAT by PKA. In the pineal glands of nocturnal animals, both gene transcription and enzyme activation necessary for transforming serotonin into $N$-acetylserotonin are regulated by $\beta$-adrenoceptor activation while in humans (diurnal animals) the gene is constitutively transcribed [23]. Thus, in humans, the activation of the enzyme is the only step regulated by darkness.

Until now, only PAMPs and DAMPs, such as LPS and zymosan, were shown to induce the synthesis of melatonin in macrophages and lymphocytes $[5,6,15-17,19]$. Macrophages express $\beta$-adrenoceptors $[24,25]$, which can be activated autocrinally by locally synthesized catecholamines, and/or by noradrenaline released by sympathetic nerve terminals $[25,26]$. Stimulation of $\alpha 2$ adrenoceptors potentiates tissue injury induced by PAMPs [24-26], while activation of $\beta 2$-adrenoceptors reduces tumor necrosis factor $[27,28]$, metalloproteinase-12 protein and monocyte chemoattractant protein-1 (MCP-1) synthesis [29]. Consequently, $\beta 2$-adrenergic stimulation reduces macrophage [26] and neutrophil [27] mobility, favoring the predominance of macrophages with a resolution phase phenotype.

Despite the strong evidence that adrenergic signaling modulates macrophage function, and that adrenoceptor/cAMP/PKA is the pivotal pathway for triggering melatonin synthesis in pinealocytes, no study has addressed the possibility that activation of $\beta$-adrenoceptors induces the synthesis of melatonin by macrophages or other immunocompetent cells. In addition to macrophages [4-6], dendritic cells (DCs), which act as the link between the innate and adaptive immunity [30], are potential candidates for synthesizing melatonin. Here we show that $\beta$-adrenergic stimulation triggers the synthesis of melatonin in primary culture bone marrow-derived dendritic cells and the murine cell line RAW 264.7. By using different pharmacological tools, we disclosed the signaling pathway involved in melatonin synthesis in macrophages, evidencing the key role of the transcription factor NF- $\mathrm{KB}$ in underlying this phenomenon. The similarities and specificity of the signaling pathways involved in melatonin synthesis in pinealocytes and in macrophages are discussed, as well as their relevance for shuttling melatonin production from pineal to extra-pineal cells. 


\section{Results}

Figure 1 shows activation of $\beta$-adrenoceptors in DCs and RAW 264.7 by isoprenaline induced melatonin synthesis. No melatonin was detected in DC incubated with the vehicle. The amount of melatonin measured in the medium of RAW 264.7 line cells was just above the detection limit.
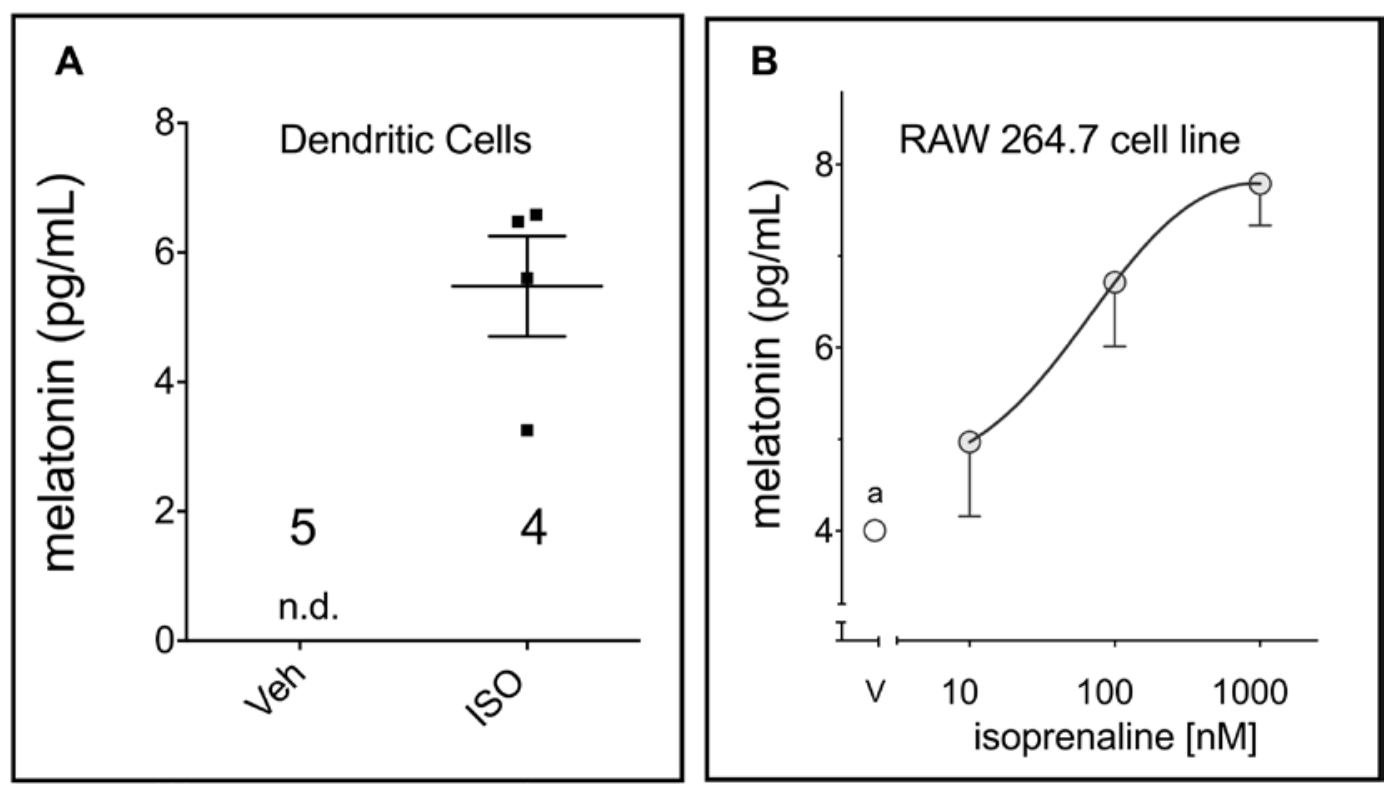

Figure 1. $\beta$-adrenoceptor triggers melatonin synthesis in phagocytes. (A) Bone marrow dendritic cells (isoprenaline, ISO, $10 \mu \mathrm{M}, 24$ h; n.d., not detected); the values for each replicate and the mean \pm SEM are shown in the graph. (B) RAW 264.7 macrophages isoprenaline $3 \mathrm{~h}$ (a)—vehicle $=4.0 \pm 0.01$, the melatonin ELISA kit detection limit is quoted as 3-4 pg/mL). Data are shown as mean $\pm \mathrm{SEM}$ of three independent experiments.

We next evaluated the mechanism of action underlying $\beta$-adrenoceptor-induced melatonin synthesis by determining the expression levels of the key enzyme controlled by adrenergic stimulation in the pineal gland and the corresponding signaling pathways. Non-stimulated RAW 264.7 macrophages expressed low levels of AANAT and P-AANAT (Figure 2A). Similar to that observed in pinealocytes, both noradrenaline and adrenaline increased the protein levels of AANAT and P-AANAT in a dose-dependent manner (Figure 2B). As the increase in AANAT is much smaller (less than two-fold) than the increase in P-AANAT (four to five-fold), we also present the data in adjusted scales to show the statistical difference between the maximal responses of vehicle- and catecholamine-treated cells (Figure 2C).

The effect of adrenaline and noradrenaline on the induction of P-AANAT was mediated by $\beta$-adrenoceptors, as it was blocked by propranolol (Figure 3A). As P-AANAT is the stable and active form of the enzyme, we confirmed that melatonin synthesis follows P-AANAT levels by measuring the melatonin content released in the culture medium by cells treated or not with propranolol $30 \mathrm{~min}$ before the addition of adrenaline or noradrenaline (Figure $3 \mathrm{~B}$ ). The equieffective concentrations of adrenaline $(0.4 \mathrm{nM})$ and noradrenaline $(0.2 \mathrm{nM})$ were chosen for evaluating the effect of the antagonists, as they were the minimal concentration of each drug that attained the maximum response. 
A

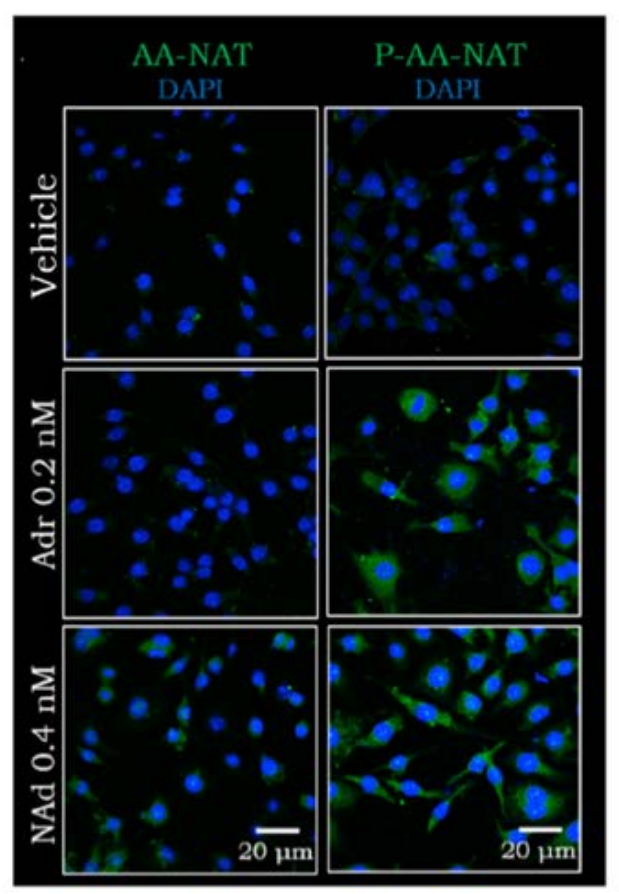

B
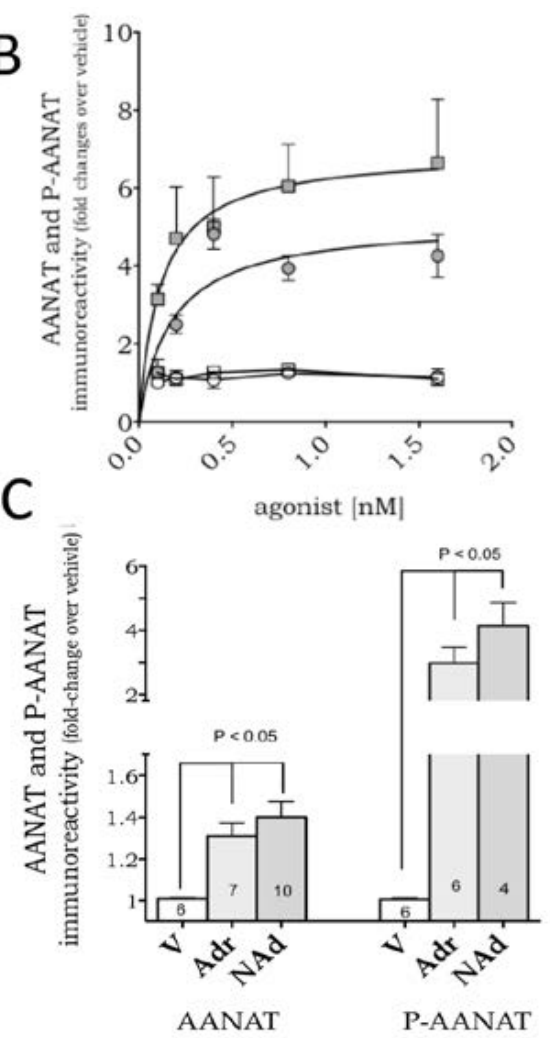

Figure 2. Adrenaline and noradrenaline induce expression of AANAT and P-AANAT in RAW 264.7 macrophages. (A) Representative immunofluorescence showing AANAT or P-AANAT expression in the cytoplasm of cells stimulated with adrenaline (Adr, $0.2 \mathrm{nM}$ ) or noradrenaline (NAd, $0.4 \mathrm{nM}$ ). The enzyme expression is shown in green, and the nuclei are stained by DAPI (blue); (B) Dose-response curve of AANAT (white symbols) and P-AANAT (grey symbols) expression in RAW 264.7 cells incubated with increasing concentrations of adrenaline (circles) or noradrenaline (squares); (C) The same data presented in (B), of AANAT and P-AANAT expression induced by adrenaline $(0.2 \mathrm{nM})$ and noradrenaline $(0.4 \mathrm{nM})$, compared to vehicle $(\mathrm{V} ; 0.001 \%$ ethanol) and plotted as single concentrations to better compare the catecholamines effect on both enzymatic forms. Data are shown as mean $\pm S E M$, normalized by the respective vehicle group. Data represent the mean of four to ten independent experiments.

To further characterize the system, we evaluated the signaling pathways involved in catecholamine-induced melatonin synthesis in macrophages. The two pathways tested were the cAMP/PKA pathway, known to trigger transcriptional and post-transcriptional regulation of Aanat in pineal glands, and the transcription factor NF- $\mathrm{KB}$, which induces the transcription of Aanat in mouse macrophage cell line RAW 264.7 and in human colostral mononuclear cells $[9,10,20]$. Pre-incubation with the inhibitor of PKA, H-89 (100 nM, $30 \mathrm{~min})$, blocked adrenaline- $(0.2 \mathrm{nM})$ and noradrenaline $(0.4 \mathrm{nM})$-induced expression and phosphorylation of AANAT (Figure 4).

Inhibiting the binding of NF-kB dimers to DNA with PDTC $(25 \mu \mathrm{M})$ completely abolished adrenaline- and noradrenaline-induced increase in P-AANAT and melatonin levels) (Figure 5). Similar results were obtained by inhibiting the degradation of IкB $\alpha$ (nuclear factor of kappa light polypeptide gene enhancer in B-cells inhibitor, alpha), which retains NF- $\mathrm{kB}$ dimers in the cytoplasm, by using $\operatorname{ALLN}(50 \mu \mathrm{M})$ (Figure 5). 

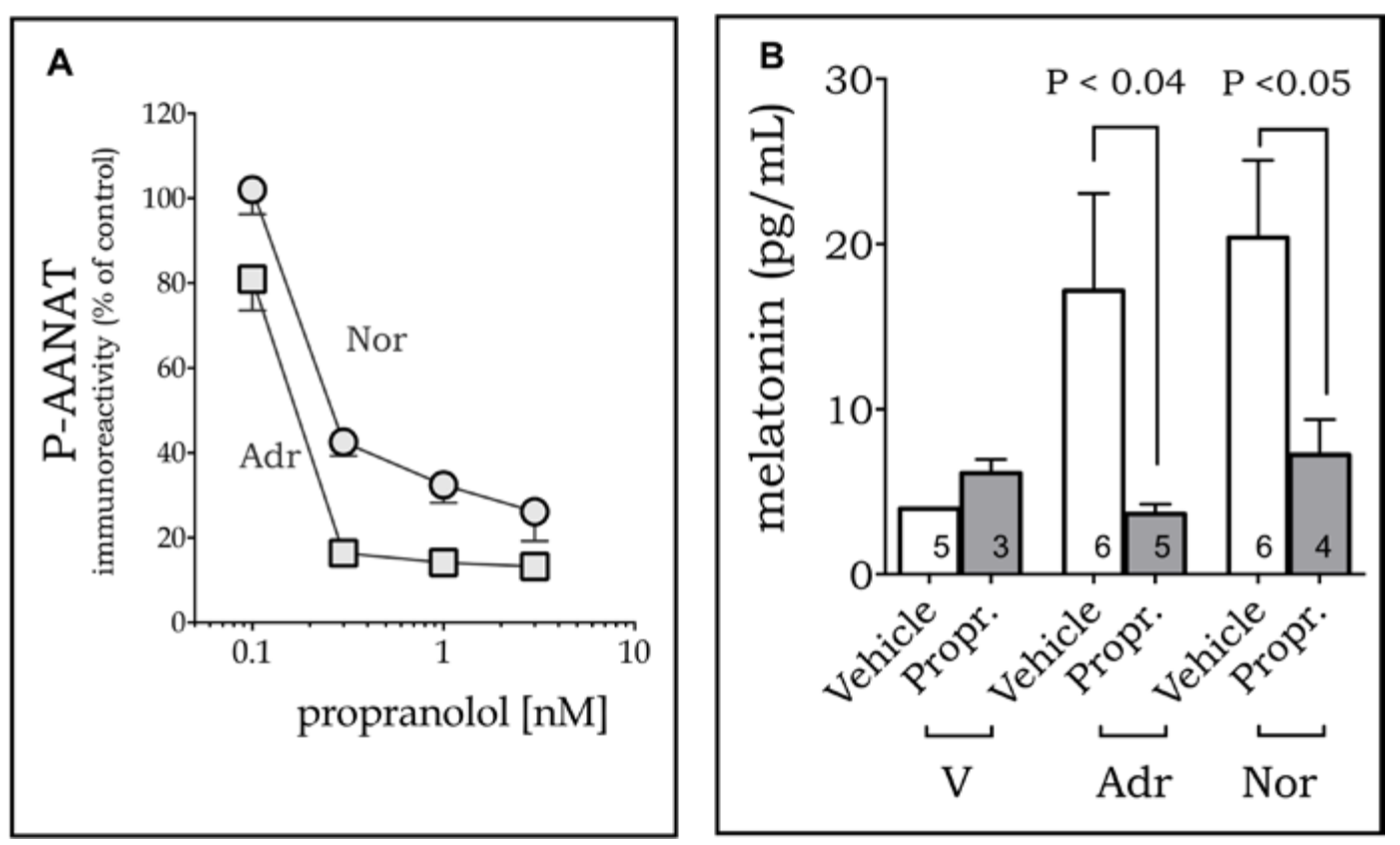

Figure 3. $\beta$-adrenoceptors mediate melatonin synthesis in RAW 264.7 macrophages. Propranolol (Prop.; $30 \mathrm{~min}$ ) inhibits P-AANAT expression (A) and melatonin synthesis (B) induced by adrenaline (Adr; $0.2 \mathrm{nM}$; squares) and noradrenaline (Nor; $0.4 \mathrm{nM}$; circles). $\mathrm{V}=$ vehicle ( $0.001 \%$ ethanol). Data represent mean \pm SEM (A)-each point is the mean of three to six independent experiments; (B) - the number of experiments is shown inside the bars).

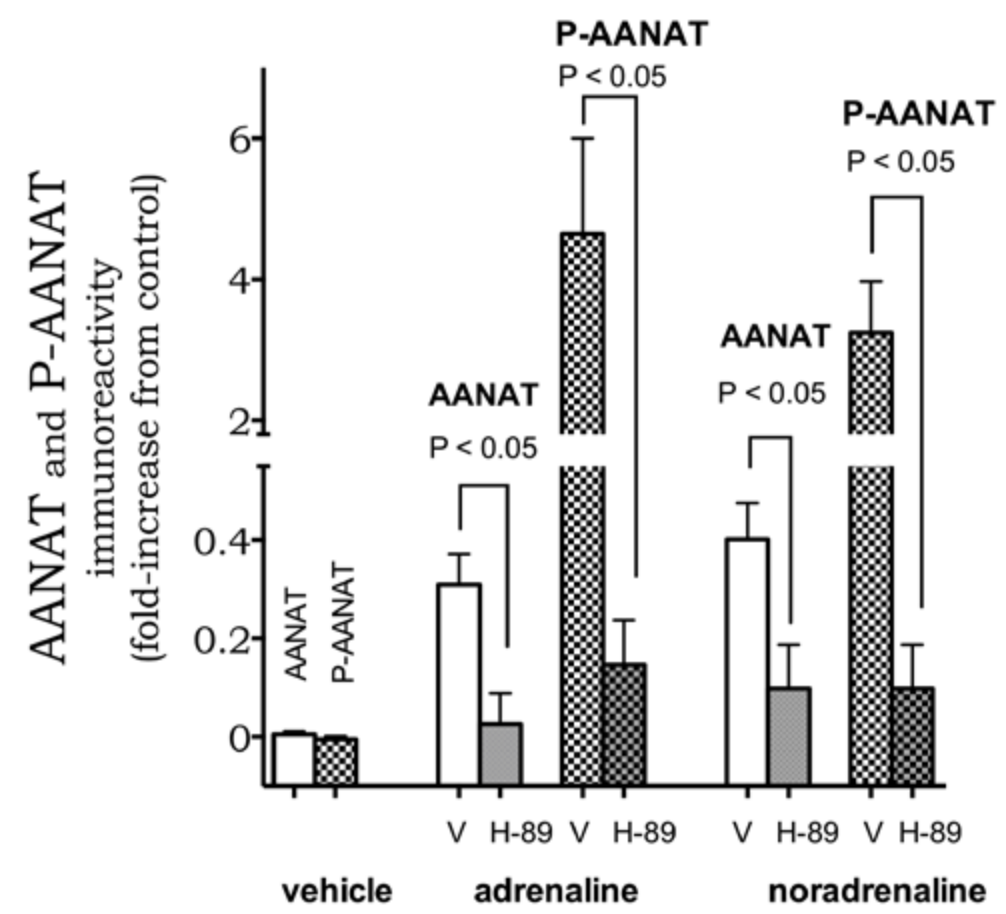

Figure 4. PKA activity modulates AANAT and P-AANAT expression. PKA inhibitor H-89 (H, $100 \mathrm{nM}$, $30 \mathrm{~min})$ inhibits adrenaline $(0.4 \mathrm{nM})$ and noradrenaline $(0.2 \mathrm{nM})$-induced increase in AANAT (open bars) and P-AANAT (crosshatched) immunoreactivity. Data represent mean \pm SEM of three to six independent experiments. $\mathrm{V}=$ vehicle $(0.001 \%$ ethanol $)$. 


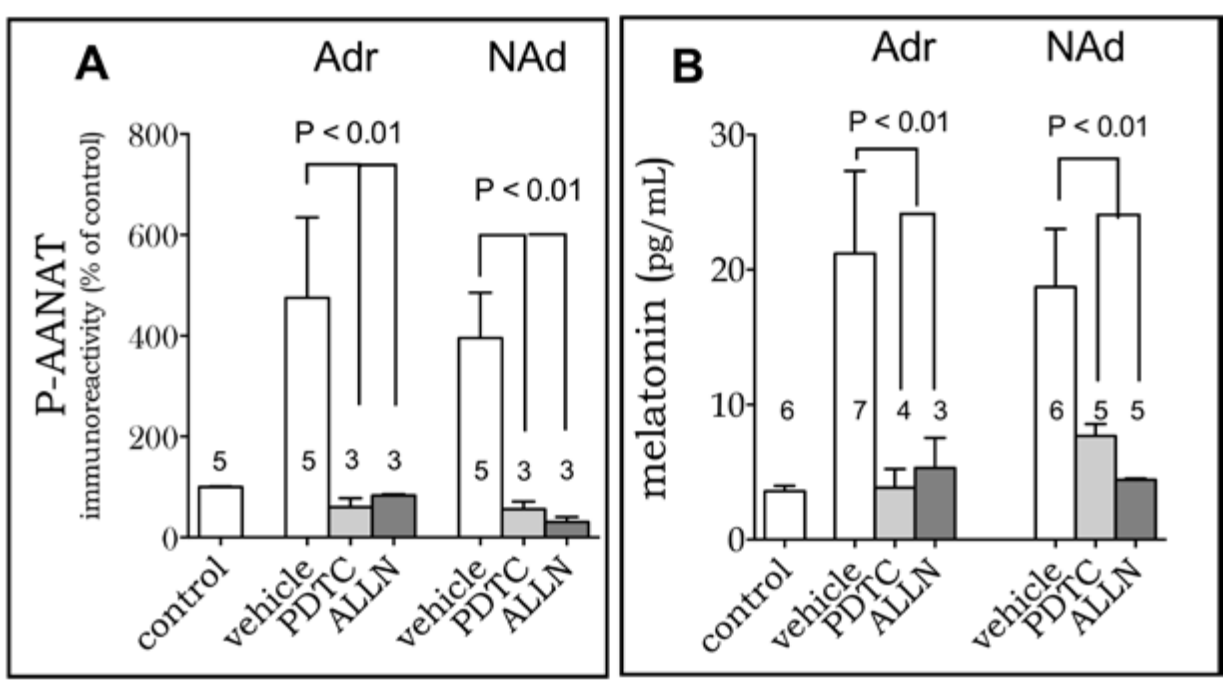

Figure 5. The transcription factor NF- $\kappa$ B mediates melatonin synthesis in RAW 264.7 cells. PDTC (P, 25 $\mu \mathrm{M}, 30 \mathrm{~min}$ ) or ALLN (A, $50 \mu \mathrm{M}, 30 \mathrm{~min}$ ) blocked Adr and Nor-induced increase in the expression of PAANAT (A) and melatonin production (Adr, 0.2nM; NAd, $0.4 \mathrm{nM}, 3 \mathrm{~h}$ ). (B) Data are shown as mean $\pm \mathrm{SEM}$; the number of replicates is shown in the graph. P-AANAT expression was normalized by the vehicle group.

\section{Discussion}

The central question of this study was whether the activation of adrenoceptors could induce melatonin production by phagocytes, such as dendritic cells and macrophages, as observed in pinealocytes. Activated phagocytes are known to synthesize melatonin, which acts autocrinally enhancing the phagocytic ability and reducing the activity of enzymes involved in the pro-inflammatory phase of the defense response [6,31].

Following the same mechanism of action observed in the pinealocytes, here we show that activation of $\beta$-adrenoceptors promotes the expression and phosphorylation of AANAT in phagocytes. The increase in P-AANAT levels was much more robust than that of AANAT, probably because most of the newly translated protein is immediately phosphorylated by the same $\beta$-adrenergic/PKA signaling pathway (Figure 6 summarizes the discussion). As observed in pinealocytes [23], the synthesis of melatonin induced by $\beta$-adrenoceptors activation depends on PKA, which phosphorylates AANAT in serine/threonine residues stabilizing the protein and allowing the conversion of serotonin into $\mathrm{N}$-acetylserotonin [31,32]. Alternatively, this difference in AANAT/P-AANAT levels can be explained by the fact that the non-phosphorylated enzyme is ubiquitinated and degraded by the proteasome, while the phosphorylated enzyme binds to the chaperone 14-3-3, which hinders its degradation [33]. 


\section{IMMUNE-PINEAL AXIS}

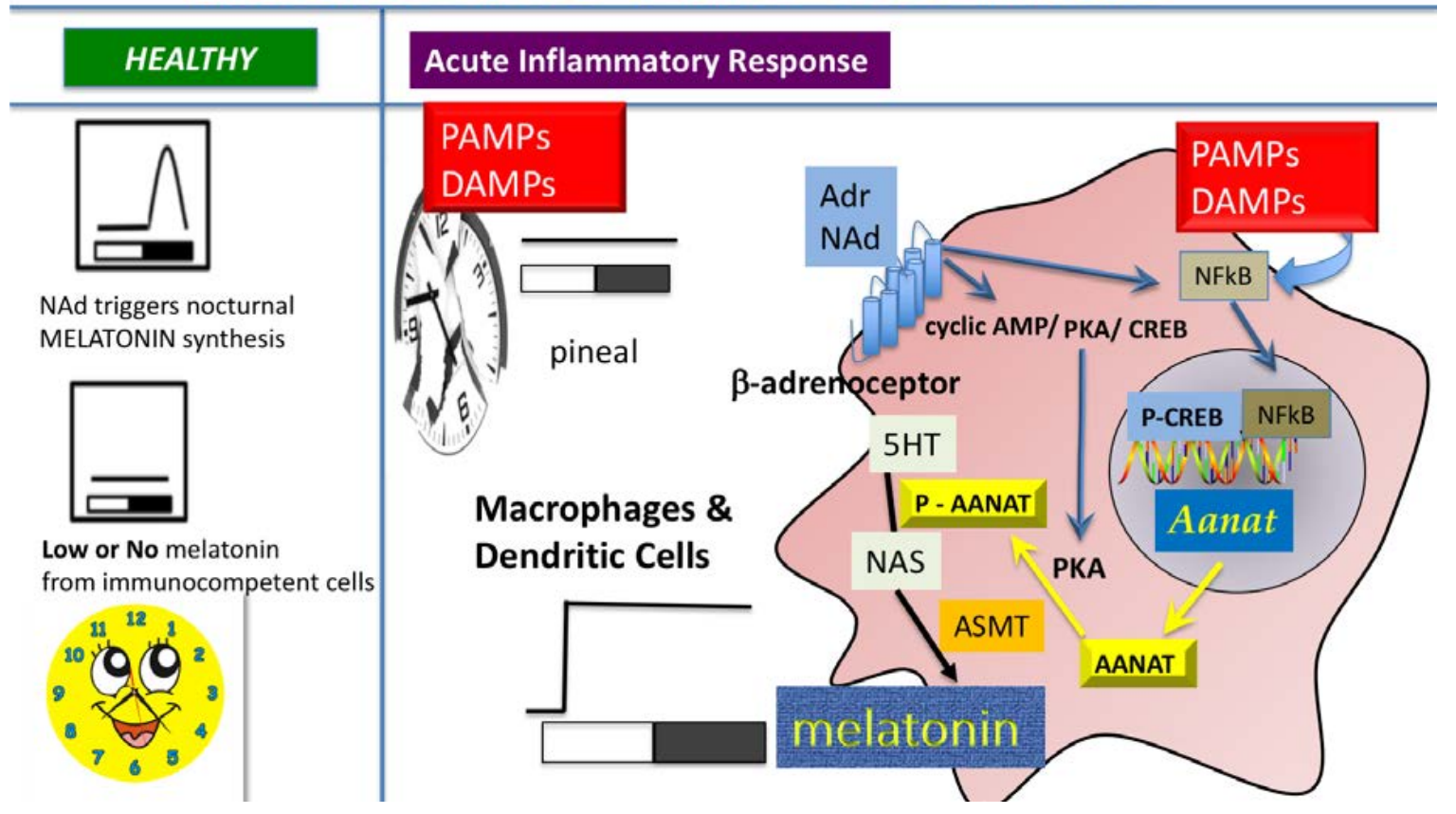

Figure 6. The Immune-Pineal Axis-Catecholamines induce melatonin synthesis in macrophages-Pathogen- and damage-associated molecular patterns (PAMPs and DAMPs), such as lipopolysaccharide (LPS), $\beta$-amyloid peptide and the pro-inflammatory cytokine tumor necrosis factor (TNF), block the synthesis of melatonin by pinealocytes. Reduction of nocturnal melatonin surge favors the migration of leukocytes to the site of the lesion. The same PAMPs/DAMPs induce the synthesis of melatonin in macrophages, microglia, and dendritic cells. This switch in melatonin source allows the migration of cells to the site of lesion, where, locally synthesized melatonin plays regulatory roles. Interestingly, activation of $\mathrm{NF}_{\kappa} \mathrm{B}$ is the key mechanism for blocking/inducing melatonin synthesis in pinealocytes/macrophages, as it regulates the transcription of the gene coding the enzyme (AA-NAT) that catalyzes the conversion of serotonin in $N$-acetylserotonin, the immediate precursor of melatonin [4,34]. One of the open questions in this system was whether catecholamines might lead to melatonin synthesis in macrophages/monocytes as it does in the pineal gland. Here we showed that activation of $\beta$-adrenoceptors induces the transcription of Aanat in a PKA and NF- $\mathrm{kB}$ dependent manner.

In contrast to AANAT, the transcription factor NF- $\mathrm{BB}$ has opposite effects in pinealocytes and macrophages. In rat pinealocytes, NF- $\mathrm{kB}$ nuclear translocation is rhythmic and synchronized to the environmental photoperiod information. The expression of the genes related to inflammatory responses presented a daily rhythm in the pineal gland of healthy rats [35,36]. At dusk, the expression of the genes encoding for toll-like receptors, cytokines, NF- $\mathrm{kB}$ subunits and related molecules, adhesion molecules, caspases and inducible nitric oxide synthase presented a very fast decrease between animals killed minutes before or after darkness [36]. The sympathetic induction of the transcription of Aanat and the synthesis of melatonin required the reduction of the nuclear content of NF- $\kappa B$ dimers, which occurs just after the lights turn off [35]. Interestingly, the gene that encodes for the NF- $\mathrm{kB} /$ RelA subunit, which regulates the expression of the genes that trigger the pro-inflammatory response, did not show a rhythmic variation during the day in healthy animals [36]. On the other hand, the increase in nuclear NFKB triggered by toll-like receptor 4 or tumor necrosis factor receptor impairs the transcription of Aanat [36-39] and the nocturnal peak of plasma melatonin [10]. In macrophages, both the adrenergic input and the nuclear translocation of NF- $\mathrm{KB}$ promote the synthesis of melatonin $[3,22]$. 
The explanation for this paradoxical response to NF- $\mathrm{KB}$ activation is that the dimers of NF- $\mathrm{KB}$ translocated to the nucleus of pinealocytes and macrophages are different. In the pinealocytes we observed the mobilization of p50/p50 dimers, which do not contain the transactivating domain, and therefore blocks Aanat transcription, while in macrophages the activated NF-kB dimers contain c-Rel, a transactivating domain positive subunit, which promotes the transcription of Aanat [22,36].

In macrophages, activation of $\beta$-adrenoceptors induces nuclear translocation of NF- $k \mathrm{~B}$, while the internalization of the complex $\beta$-adrenoceptors/ $\beta$-arrestin upon receptor stimulation impairs the degradation of IкB by the proteasome and the nuclear translocation of NF- $\kappa B$ [39-42]. Thus, activation of $\beta$-adrenoceptors or sympathetic stimulation reduces the pro-inflammatory phenotype of macrophages. Indeed, $\beta$-arrestin 2 inhibits excessive inflammation in infiltrated macrophages after myocardial infarction [43]. In U937 macrophages, noradrenaline induced increased IL-6 mRNA, while propranolol or PDTC reduced the production of IL-6 [44]. Besides regulating the expression of proand anti-inflammatory cytokines, here we show that the activation of $\beta$-adrenoceptors also leads to melatonin synthesis, which maintains the macrophages in an M2 phenotype.

Extra-pineal synthesis of melatonin by cerebellar cells decreases LPS-induced neuronal death [45], melatonin synthesis by human glioma cell lines is inversely correlated with tumor aggressiveness [46], and the increase in daytime plasma melatonin concentration is associated with faster surgical (laparotomy) wound-healing [47], reinforcing the anti-inflammatory role of locally synthesized melatonin. Recently, it was shown that neuronal cells also produce melatonin and, intriguingly, this production is located in the mitochondria [48]. Indeed, all the molecular machinery necessary for melatonin synthesis, including AANAT, ASMT and 14-3-3, was found in the mitochondria matrix, and brain-derived isolated mitochondria were able to convert serotonin into melatonin [48]. Whether melatonin synthesis and signaling by other cell types, such as macrophages and tumoral cells, also rely on mitochondrial location remains to be investigated.

Here we showed that stimulation of $\beta$-adrenoceptors induces melatonin synthesis in both BM-DCs and RAW 264.7 cells. Regarding the dendritic cells, it is well-known that these specialized phagocytes are responsible for bridging innate and adaptive immune responses [49], and that $\beta$-stimulation turns DCs to an anti-inflammatory state [50] and triggers $\mathrm{T}$ cell differentiation [51]. Indeed, sympathetic stimulation is essential for triggering the recovery phase of an immune response $[52,53]$ in lymph nodes [54], bone marrow cells [55], and gut macrophages [56]. Melatonin produced on demand by immune cells $[1,31]$ could represent a new player in the defense response not only directed to PAMPs and DAMPs but also mediated by activation of the sympathetic nervous system [57]. Taken together, our data provide further support to the new concept of endogenously and extra-pineal produced melatonin as an integral player in the function of phagocytes in situations of infection and/or sympathetic activation.

\section{Materials and Methods}

\subsection{Drugs and Reagents}

The reagents adrenaline, noradrenaline, isoprenaline, propranolol, H-89 (PKA inhibitor), the primary antibodies (anti AANAT: S0564; and anti-phospho AANAT: 0939), the secondary FITC-labelled antibody (S0814), and 4',6-diamidino-2-phenylindole (DAPI) were purchased from Sigma-Aldrich (St. Louis, MO, USA). RPMI 1640 medium and fetal bovine serum were purchased from Gibco-Life Technologies (Grand Island, New York, NY, USA). The NF-kB blockers acetyl-L-leucyl-L-leucyl-L-norleucinal (ALLN) and pyrrolidine dithiocarbamate (PDTC) were purchased from Tocris (Minneapolis, MN, USA). The recombinant murine granulocyte-macrophage colony-stimulating factor (rmGM-CSF) were obtained from Peprotech (Rocky Hill, NJ, USA). All reagents were of analytical grade. 


\subsection{Mice}

Eight- to ten-week-old BALB/c male mice were obtained from the Department of Immunology Animal Facility at the University of São Paulo and kept in micro-isolator cages under specific pathogen-free conditions. Experiments were performed following the guidelines for animal use and care approved by the Institutional Animal Care and Use Committee at the Institute of Biomedical Sciences of the University of São Paulo (CEUA-ICB/USP: n. 044, p. 31, b. 03/approved 27 May 2015).

\subsection{Bone Marrow-Derived DC Generation and Culture}

Bone-marrow-DCs were derived in vitro from bone marrow cells as previously described [58], and were characterized as CD11c/MHCII ${ }^{+}$cells. Briefly, bone marrow cells were collected from the femur of BALB/c mice and cultured in RPMI 1640 medium (GIBCO, Grand Island, New York, NY, USA) supplemented with 10\% heat-inactivated fetal bovine serum (FBS-GIBCO, Goiância, Brazil) and with antibiotic-antimycotic solution (GIBCO, Grand Island, New York, NY, USA). Cells were cultured for six days in tissue culture dishes (Becton Dickinson, Franklin Lakes, NJ, USA) in a total volume of $12 \mathrm{~mL}$ of medium with $20 \mathrm{ng} / \mathrm{mL}$ of recombinant murine granulocyte-macrophage colony-stimulating factor (rmGM-CSF). Half of the medium was replaced, and rmGM-CSF stimulation renewed on day 3 of culture. On day 6, non-adherent cells were collected and transferred to 24-well plates $\left(2 \times 10^{6}\right.$ cell/well). Cells were treated with isoprenaline $(10 \mathrm{nM})$ for $24 \mathrm{~h}$ and supernatants collected for melatonin measurement.

\subsection{Cell Line RAW 264.7 Cultures}

The in vitro studies were performed using the model of murine macrophage cell line RAW 264.7 cultured $\left(37^{\circ} \mathrm{C}, 5 \%, \mathrm{CO}_{2}\right)$ in RPMI 1640 medium supplemented with $10 \%$ FBS. The experiments were performed in cells plated at $2 \times 10^{6}$ cells/well for melatonin measurement, and $2 \times 10^{5}$ cells / well for immunofluorescence assays in medium without FBS.

\subsection{Immunofluorescence Detection of the Enzyme AANAT}

Adrenaline (Adr) and noradrenaline (NAd)-induced expression of AA-NAT and P-AA-NAT was evaluated in RAW 264.7 cells $\left(2 \times 10^{5}\right.$ cells / well) plated in 8-well chamber slides (Nunc, Sigma-Aldrich, Rochester, NY, USA). The agonists at concentrations ranging from $0.1 \mathrm{nM}$ to $1.6 \mathrm{nM}$ were incubated for $15 \mathrm{~min}$. The effect of the $\beta$-adrenoceptor antagonist, propranolol $(0.1,0.3,1$ and $3 \mathrm{nM})$, the PKA inhibitor (H-89; $100 \mathrm{nM})$, or the NF- $\mathrm{kB}$ inhibitors, [ALLN $(50 \mu \mathrm{M})$ and PDTC $(25 \mu \mathrm{M})$ ] was tested against equieffective concentrations of adrenaline $(0.2 \mathrm{nM})$ and noradrenaline $(0.4 \mathrm{nM})$. The inhibitors were incubated for $30 \mathrm{~min}$ before adding the agonists, and the control cells were incubated with $0.001 \%$ ethanol in RPMI medium. After the incubation time, cells were fixed with methanol/acetone $\left(1: 1 ; 15 \mathrm{~min}\right.$ at $\left.-20^{\circ} \mathrm{C}\right)$, permeabilized with $0.5 \%$ saponin $(10 \mathrm{~min}$, room temperature) and incubated overnight $\left(4^{\circ} \mathrm{C}\right.$ ) with antibodies anti-AANAT (dilution 1:200) or anti-phospho-AANAT (dilution 1:300). The next day, the primary antibodies were revealed by the secondary FITC-labeled antibody (dilution 1:200, $1 \mathrm{~h}$ at room temperature). During the last five min, cell nuclei were stained with DAPI (1:1000). The slides were analyzed by confocal microscopy (Leica SP8 microscope, and an LSM 510, Carl Zeiss, Jena, Germany) using a 63 oil-immersion objective. FITC was excited using the 488 laser and the emitted fluorescence was measured at $525 \mathrm{~nm}$. Images were taken from four randomly chosen fields in each well ( $\approx 30$ cells/field), and the fluorescence intensity was quantified using ImageJ 1.41 software (http://rsb.info.nih.gov/ij).

\subsection{Melatonin Dosage}

Melatonin content was measured in the supernatant of RAW 264.7 macrophages or BM-DCs (both $2 \times 10^{6}$ cells/well $/ 500 \mu \mathrm{L}$ ) treated with adrenaline, noradrenaline or isoprenaline for $3 \mathrm{~h}$. The blockers propranolol (0.3 nM), PDTC (25 M), or ALLN (50 M) were incubated for $30 \mathrm{~min}$ before 
adding the agonists $(3 \mathrm{~h}$ ). The experiments for detecting the expression of the enzymes required only $15 \mathrm{~min}$ incubation with the agonists, while for melatonin measurement a $3 \mathrm{~h}$ treatment was required. Melatonin was detected by commercial ELISA kit (Melatonin ELISA, IBL, Hamburg, Germany). The detection limit of the kit is $3.0-4.0 \mathrm{pg} / \mathrm{mL}$.

\subsection{Statistical Analyses}

Data are expressed as mean \pm SEM Groups were compared by one-way analysis of variance (ANOVA) followed by the Newman-Keuls post-test. $p$ values lower than 0.05 were considered statistically significant. GraphPad Prism ${ }^{\circledR}$ version 5.00 (GraphPad Software@, San Diego, CA, USA) was used for analysis of the data.

\section{Conclusions}

Melatonin is not only synthesized by the pineal gland and/or linked to environmental darkness. Activated immune-competent cells synthesize melatonin, which plays a role in regulating inflammatory responses. Here we showed that besides PAMPs and DAMPs, catecholamines also trigger melatonin synthesis in dendritic cells and macrophages. This effect is mediated by $\beta$-adrenoceptor/cAMP/PKA, which increases the expression of AA-NAT and its phosphorylation. Interestingly, as observed for PAMPs and DAMPs, catecholamines also trigger the NF- $\mathrm{kB}$ signaling pathway, which is responsible for Aanat transcription. Taken together, our data provide further support to the new concept of endogenously and extra-pineal produced melatonin as an integral player in the function of phagocytes in situations of infection and/or sympathetic activation.

Author Contributions: M.A.P.-L. designed, performed and analyzed the experiments and participated in writing the paper; E.C. performed some experiments and participated in writing the paper; C.E.C.-S. performed some experiments; P.A.F. performed experiments and wrote the paper; and R.P.M. conceived the work, designed the experiments, analyzed the data and wrote the paper.

Funding: This work was supported by grants to R.P.M. from the Fundação de Amparo à Pesquisa do Estado de São Paulo (FAPESP; 2013/13691-1), and from the National Council for Science and Development (CNPq: 480097/2013-5). M.A.P.-L. was supported by a doctoral fellowship of Coordenação de Aperfeiçoamento do Pessoal do Ensino Superior (CAPES), C.E.C.-S and E.C. (FAPESP 2009/17923-9 were supported by FAPESP fellowships. R.P.M. is a senior fellow of CNPq (304637/2013-0).

Acknowledgments: The authors gratefully thank Débora Aparecida Moura (CNPq technical fellow) and Eduardo Braga for technical assistance. The authors gratefully thank the National Institute of Pharmacology (INFAR) Multiuser Facility of the Federal University of São Paulo (UNIFESP), for the use of the confocal microscope Leica SP8.

Conflicts of Interest: The authors declare no conflict of interest.

\section{References}

1. Carrillo-Vico, A.; Lardone, P.J.; Alvarez-Sánchez, N.; Rodríguez-Rodríguez, A.; Guerrero, J.M. Melatonin: Buffering the immune system. Int. J. Mol. Sci. 2013, 14, 8638-8683. [CrossRef] [PubMed]

2. Lotufo, C.M.; Lopes, C.; Dubocovich, M.L.; Farsky, S.H.; Markus, R.P. Melatonin and N-acetylserotonin inhibit leukocyte rolling and adhesion to rat microcirculation. Eur. J. Pharmacol. 2001, 430, 351-357. [CrossRef]

3. Markus, R.P.; Ferreira, Z.S.; Fernandes, P.A.; Cecon, E. The immune-pineal axis: A shuttle between endocrine and paracrine melatonin sources. Neuroimmunomodulation 2007, 14, 126-133. [CrossRef] [PubMed]

4. Markus, R.P.; Cecon, E.; Pires-Lapa, M.A. Immune-pineal axis: Nuclear factor $\kappa B(N F-\kappa B)$ mediates the shift in the melatonin source from pinealocytes to immune competent cells. Int. J. Mol. Sci. 2013, 14, 10979-10997. [CrossRef] [PubMed]

5. Muxel, S.M.; Pires-Lapa, M.A.; Monteiro, A.W.; Cecon, E.; Tamura, E.K.; Floeter-Winter, L.M.; Markus, R.P. NF- $\mathrm{kB}$ drives the synthesis of melatonin in RAW 264.7 macrophages by inducing the transcription of the arylalkylamine-N-acetyltransferase (AA-NAT) gene. PLoS ONE 2012, 7, e52010. [CrossRef] [PubMed] 
6. Pires-Lapa, M.A.; Tamura, E.K.; Salustiano, E.M.; Markus, R.P. Melatonin synthesis in human colostrum mononuclear cells enhances dectin-1-mediated phagocytosis by mononuclear cells. J. Pineal Res. 2013, 55, 240-246. [CrossRef] [PubMed]

7. Pontes, G.N.; Cardoso, E.C.; Carneiro-Sampaio, M.M.; Markus, R.P. Injury switches melatonin production source from endocrine (pineal) to paracrine (phagocytes)—melatonin in human colostrum and colostrum phagocytes. J. Pineal Res. 2006, 41, 136-141. [CrossRef] [PubMed]

8. Pontes, G.N.; Cardoso, E.C.; Carneiro-Sampaio, M.M.; Markus, R.P. Pineal melatonin and the innate immune response: The TNF-alpha increase after cesarean section suppresses nocturnal melatonin production. J. Pineal Res. 2007, 43, 365-371. [CrossRef] [PubMed]

9. Tamura, E.K.; Fernandes, P.A.; Marçola, M.; da Silveira-Cruz-Machado, S.; Markus, R.P. Long-lasting priming of endothelial cells by plasma melatonin levels. PLoS ONE 2010, 5, e13958. [CrossRef] [PubMed]

10. Goswami, S.; Haldar, C. UVB irradiation severely induces systemic tissue injury by augmenting oxidative load in a tropical rodent: Efficacy of melatonin as an antioxidant. J. Photochem. Photobiol. B 2014, 141, 84-92. [CrossRef] [PubMed]

11. Kaur, C.; Sivakumar, V.; Robinson, R.; Foulds, W.S.; Luu, C.D.; Ling, E.A. Neuroprotective effect of melatonin against hypoxia-induced retinal ganglion cell death in neonatal rats. J. Pineal Res. 2013, 54, $190-206$. [CrossRef] [PubMed]

12. Radogna, F.; Nuccitelli, S.; Mengoni, F.; Ghibelli, L. Neuroprotection by melatonin on astrocytoma cell death. Ann. N. Y. Acad. Sci. 2009, 1171, 509-513. [CrossRef] [PubMed]

13. Shin, I.S.; Park, J.W.; Shin, N.R.; Jeon, C.M.; Kwon, O.K.; Kim, J.S.; Kim, J.C.; Oh, S.R.; Ahn, K.S. Melatonin reduces airway inflammation in ovalbumin-induced asthma. Immunobiology 2014, 219, 901-908. [CrossRef] [PubMed]

14. Acuña-Castroviejo, D.; Escames, G.; Venegas, C.; Díaz-Casado, M.E.; Lima-Cabello, E.; López, L.C.; Rosales-Corral, S.; Tan, D.X.; Reiter, R.J. Extrapineal melatonin: Sources, regulation, and potential functions. Cell. Mol. Life Sci. 2014, 71, 2997-3025. [CrossRef] [PubMed]

15. Carrillo-Vico, A.; Calvo, J.R.; Abreu, P.; Lardone, P.J.; García-Mauriño, S.; Reiter, R.J.; Guerrero, J.M. Evidence of melatonin synthesis by human lymphocytes and its physiological significance: Possible role as intracrine, autocrine, and/or paracrine substance. FASEB J. 2004, 18, 537-539. [CrossRef] [PubMed]

16. Lardone, P.J.; Carrillo-Vico, A.; Naranjo, M.C.; De Felipe, B.; Vallejo, A.; Karasek, M.; Guerrero, J.M. Melatonin synthesized by Jurkat human leukemic T cell line is implicated in IL-2 production. J. Cell. Physiol. 2006, 206, 273-279. [CrossRef] [PubMed]

17. Conti, A.; Conconi, S.; Hertens, E.; Skwarlo-Sonta, K.; Markowska, M.; Maestroni, J.M. Evidence for melatonin synthesis in mouse and human bone marrow cells. J. Pineal Res. 2000, 28, 193-202. [CrossRef] [PubMed]

18. Finocchiaro, L.M.; Nahmod, V.E.; Launay, J.M. Melatonin biosynthesis and metabolism in peripheral blood mononuclear leucocytes. Biochem. J. 1991, 280, 727-731. [CrossRef] [PubMed]

19. Laranjeira-Silva, M.F.; Zampieri, R.A.; Muxel, S.M.; Floeter-Winter, L.M.; Markus, R.P. Melatonin attenuates Leishmania (L.) amazonensis infection by modulating arginine metabolism. J. Pineal Res. 2015, 59, 478-487. [CrossRef] [PubMed]

20. Simonneaux, V.; Ribelayga, C. Generation of the melatonin endocrine message in mammals: A review of the complex regulation of melatonin synthesis by norepinephrine, peptides, and other pineal transmitters. Pharmacol. Rev. 2003, 55, 325-395. [CrossRef] [PubMed]

21. Muxel, S.M.; Laranjeira-Silva, M.F.; Carvalho-Sousa, C.E.; Floeter-Winter, L.M.; Markus, R.P. The RelA/cRel nuclear factor- $\mathrm{KB}(\mathrm{NF}-\mathrm{kB})$ dimer, crucial for inflammation resolution, mediates the transcription of the key enzyme in melatonin synthesis in RAW 264.7 macrophages. J. Pineal Res. 2016, 60, 394-404. [CrossRef] [PubMed]

22. Biswas, S.K.; Mantovani, A. Macrophage plasticity and interaction with lymphocyte subsets: Cancer as a paradigm. Nat. Immunol. 2010, 11, 889-896. [CrossRef] [PubMed]

23. Gastel, J.A.; Roseboom, P.H.; Rinaldi, P.A.; Weller, J.L.; Klein, D.C. Melatonin production: Proteasomal proteolysis in serotonin $N$-acetyltransferase regulation. Science 1998, 279, 1358-1360. [CrossRef] [PubMed]

24. Flierl, M.A.; Rittirsch, D.; Nadeau, B.A.; Chen, A.J.; Sarma, J.V.; Zetoune, F.S.; McGuire, S.R.; List, R.P.; Day, D.E.; Hoesel, L.M.; et al. Phagocyte-derived catecholamines enhance acute inflammatory injury. Nature 2007, 449, 721-725. [CrossRef] [PubMed] 
25. Flierl, M.A.; Rittirsch, D.; Nadeau, B.A.; Sarma, J.V.; Day, D.E.; Lentsch, A.B.; Huber-Lang, M.S.; Ward, P.A. Upregulation of phagocyte-derived catecholamines augments the acute inflammatory response. PLoS ONE 2009, 4, e4414. [CrossRef] [PubMed]

26. Elenkov, I.J.; Wilder, R.L.; Chrousos, G.P.; Vizi, E.S. The sympathetic nerve-an integrative interface between two supersystems: The brain and the immune system. Pharmacol. Rev. 2000, 52, 595-638. [PubMed]

27. Bosmann, M.; Grailer, J.J.; Zhu, K.; Matthay, M.A.; Sarma, J.V.; Zetoune, F.S.; Ward, P.A. Anti-inflammatory effects of $\beta 2$ adrenergic receptor agonists in experimental acute lung injury. FASEB J. 2012, 26, 2137-2144. [CrossRef] [PubMed]

28. Tang, S.T.; Su, H.; Zhang, Q.; Tang, H.Q.; Wang, C.J.; Zhou, Q.; Wei, W.; Zhu, H.Q.; Wang, Y. Melatonin Attenuates Aortic Endothelial Permeability and Arteriosclerosis in Streptozotocin-Induced Diabetic Rats: Possible Role of MLCK- and MLCP-Dependent MLC Phosphorylation. J. Cardiovasc. Pharmacol. Ther. 2016, 21, 82-92. [CrossRef] [PubMed]

29. Assis-de-Brito, T.L.; Monte-Alto-Costa, A.; Romana-Souza, B. Propranolol impairs the closure of pressure ulcers in mice. Life Sci. 2014, 100, 138-146. [CrossRef] [PubMed]

30. Banchereau, J.; Steinman, R.M. Dendritic cells and the control of immunity. Nature 1998, 392, $245-252$. [CrossRef] [PubMed]

31. Jockers, R.; Delagrange, P.; Dubocovich, M.L.; Markus, R.P.; Renault, N.; Tosini, G.; Cecon, E.; Zlotos, D.P. Update on melatonin receptors: IUPHAR Review 20. Br. J. Pharmacol. 2016, 173, 2702-2725. [CrossRef] [PubMed]

32. Ganguly, S.; Gastel, J.A.; Weller, J.L.; Schwartz, C.; Jaffe, H.; Namboodiri, M.A.; Coon, S.L.; Hickman, A.B.; Rollag, M.; Obsil, T.; et al. Role of a pineal cAMP-operated arylalkylamine N-acetyltransferase/14-3-3-binding switch in melatonin synthesis. Proc. Natl. Acad. Sci. USA 2001, 98, 8083-8088. [CrossRef] [PubMed]

33. Klein, D.C.; Ganguly, S.; Coon, S.; Weller, J.L.; Obsil, T.; Hickman, A.; Dyda, F. 14-3-3 Proteins and photoneuroendocrine transduction: Role in controlling the daily rhythm in melatonin. Biochem. Soc. Trans. 2002, 30, 365-373. [CrossRef] [PubMed]

34. Fernandes, P.A.; Cecon, E.; Markus, R.P.; Ferreira, Z.S. Effect of TNF-alpha on the melatonin synthetic pathway in the rat pineal gland: Basis for a 'feedback' of the immune response on circadian timing. J. Pineal Res. 2006, 41, 344-350. [CrossRef] [PubMed]

35. Cecon, E.; Fernandes, P.A.; Pinato, L.; Ferreira, Z.S.; Markus, R.P. Daily variation of constitutively activated nuclear factor kappa B (NFKB) in rat pineal gland. Chronobiol. Int. 2010, 27, 52-67. [CrossRef] [PubMed]

36. Da Silveira Cruz-Machado, S.; Tamura, E.K.; Pinato, L.; Fernandes, P.A.; Markus, R.P. Daily corticosterone rhythm modulates pineal function through NFkB-related gene transcriptional Program. Sci. Rep. 2017, 7, 2091. [CrossRef] [PubMed]

37. Da Silveira Cruz-Machado, S.; Pinato, L.; Tamura, E.K.; Carvalho-Sousa, C.E.; Markus, R.P. Glia-pinealocyte network: The paracrine modulation of melatonin synthesis by tumor necrosis factor (TNF). PLoS ONE 2012, 7, e40142. [CrossRef] [PubMed]

38. Da Silveira Cruz-Machado, S.; Carvalho-Sousa, C.E.; Tamura, E.K.; Pinato, L.; Cecon, E.; Fernandes, P.A.; de Avellar, M.C.; Ferreira, Z.S.; Markus, R.P. TLR4 and CD14 receptors expressed in rat pineal gland trigger NFKB pathway. J. Pineal Res. 2010, 49, 183-192. [CrossRef] [PubMed]

39. Witherow, D.S.; Garrison, T.R.; Miller, W.E.; Lefkowitz, R.J. beta-Arrestin inhibits NF-kappaB activity by means of its interaction with the NF-kappaB inhibitor IkappaBalpha. Proc. Natl. Acad. Sci. USA 2004, 101, 8603-8607. [CrossRef] [PubMed]

40. Loniewski, K.; Shi, Y.; Pestka, J.; Parameswaran, N. Toll-like receptors differentially regulate GPCR kinases and arrestins in primary macrophages. Mol. Immunol. 2008, 45, 2312-2322. [CrossRef] [PubMed]

41. Kizaki, T.; Izawa, T.; Sakurai, T.; Haga, S.; Taniguchi, N.; Tajiri, H.; Watanabe, K.; Day, N.K.; Toba, K.; Ohno, H. Beta2-adrenergic receptor regulates Toll-like receptor-4-induced nuclear factor-kappaB activation through beta-arrestin 2. Immunology 2008, 124, 348-356. [CrossRef] [PubMed]

42. Kizaki, T.; Shirato, K.; Sakurai, T.; Ogasawara, J.E.; Oh-ishi, S.; Matsuoka, T.; Izawa, T.; Imaizumi, K.; Haga, S.; Ohno, H. Beta2-adrenergic receptor regulate Toll-like receptor 4-induced late-phase NF-kappaB activation. Mol. Immunol. 2009, 46, 1195-1203. [CrossRef] [PubMed]

43. Watari, K.; Nakaya, M.; Nishida, M.; Kim, K.M.; Kurose, H. $\beta$-arrestin2 in infiltrated macrophages inhibits excessive inflammation after myocardial infarction. PLoS ONE 2013, 8, e68351. [CrossRef] [PubMed] 
44. Li, M.; Yao, W.; Li, S.; Xi, J. Norepinephrine induces the expression of interleukin-6 via $\beta$-adrenoreceptor-NAD $(\mathrm{P}) \mathrm{H}$ oxidase system-NF- $\mathrm{BB}$ dependent signal pathway in U937 macrophages. Biochem. Biophys. Res. Commun. 2015, 460, 1029-1034. [CrossRef] [PubMed]

45. Pinato, L.; da Silveira Cruz-Machado, S.; Franco, D.G.; Campos, L.M.; Cecon, E.; Fernandes, P.A.; Bittencourt, J.C.; Markus, R.P. Selective protection of the cerebellum against intracerebroventricular LPS is mediated by local melatonin synthesis. Brain Struct. Funct. 2015, 220, 827-840. [CrossRef] [PubMed]

46. Kinker, G.S.; Oba-Shinjo, S.M.; Carvalho-Sousa, C.E.; Muxel, S.M.; Marie, S.K.; Markus, R.P.; Fernandes, P.A. Melatonergic system-based two-gene index is prognostic in human gliomas. J. Pineal Res. 2016, 60, 84-94. [CrossRef] [PubMed]

47. De Oliveira Tatsch-Dias, M.; Levandovski, R.M.; Custódio de Souza, I.C.; Gregianin Rocha, M.; Magno Fernandes, P.A.; Torres, I.L.; Hidalgo, M.P.; Markus, R.P.; Caumo, W. The concept of the immune-pineal axis tested in patients undergoing an abdominal hysterectomy. Neuroimmunomodulation 2013, 20, $205-212$. [CrossRef] [PubMed]

48. Suofu, Y.; Li, W.; Jean-Alphonse, F.G.; Jia, J.; Khattar, N.K.; Li, J.; Baranov, S.V.; Leronni, D.; Mihalik, A.C.; $\mathrm{He}$, Y.; et al. Dual role of mitochondria in producing melatonin and driving GPCR signaling to block cytochrome c release. Proc. Natl. Acad. Sci. USA 2017, 114, E7997-E8006. [CrossRef] [PubMed]

49. Takenaka, M.C.; Guereschi, M.G.; Basso, A.S. Neuroimmune interactions: Dendritic cell modulation by the sympathetic nervous system. Semin. Immunopathol. 2017, 39, 165-176. [CrossRef] [PubMed]

50. Nijhuis, L.E.; Olivier, B.J.; Dhawan, S.; Hilbers, F.W.; Boon, L.; Wolkers, M.C.; Samsom, J.N.; de Jonge, W.J. Adrenergic $\beta 2$ receptor activation stimulates anti-inflammatory properties of dendritic cells in vitro. PLoS ONE 2014, 9, e85086. [CrossRef] [PubMed]

51. Takenaka, M.C.; Araujo, L.P.; Maricato, J.T.; Nascimento, V.M.; Guereschi, M.G.; Rezende, R.M.; Quintana, F.J.; Basso, A.S. Norepinephrine Controls Effector T Cell Differentiation through $\beta 2$-Adrenergic Receptor-Mediated Inhibition of NF-kB and AP-1 in Dendritic Cells. J. Immunol. 2016, 196, 637-644. [CrossRef] [PubMed]

52. Guereschi, M.G.; Araujo, L.P.; Maricato, J.T.; Takenaka, M.C.; Nascimento, V.M.; Vivanco, B.C.; Reis, V.O.; Keller, A.C.; Brum, P.C.; Basso, A.S. Beta2-adrenergic receptor signaling in CD4+ Foxp3+ regulatory T cells enhances their suppressive function in a PKA-dependent manner. Eur. J. Immunol. 2013, 43, 1001-1012. [CrossRef] [PubMed]

53. Nakai, A.; Hayano, Y.; Furuta, F.; Noda, M.; Suzuki, K. Control of lymphocyte egress from lymph nodes through $\beta 2$-adrenergic receptors. J. Exp. Med. 2014, 211, 2583-2598. [CrossRef] [PubMed]

54. Wirth, T.; Westendorf, A.M.; Bloemker, D.; Wildmann, J.; Engler, H.; Mollerus, S.; Wadwa, M.; Schäfer, M.K.; Schedlowski, M.; del Rey, A. The sympathetic nervous system modulates CD4(+)Foxp3(+) regulatory $\mathrm{T}$ cells via noradrenaline-dependent apoptosis in a murine model of lymphoproliferative disease. Brain Behav. Immun. 2014, 38, 100-110. [CrossRef] [PubMed]

55. Scheiermann, C.; Kunisaki, Y.; Lucas, D.; Chow, A.; Jang, J.E.; Zhang, D.; Hashimoto, D.; Merad, M.; Frenette, P.S. Adrenergic nerves govern circadian leukocyte recruitment to tissues. Immunity 2012, 37, 290-301. [CrossRef] [PubMed]

56. Gabanyi, I.; Muller, P.A.; Feighery, L.; Oliveira, T.Y.; Costa-Pinto, F.A.; Mucida, D. Neuro-immune Interactions Drive Tissue Programming in Intestinal Macrophages. Cell 2016, 164, 378-391. [CrossRef] [PubMed]

57. Fernandes, P.A.; Tamura, E.K.; D’Argenio-Garcia, L.; Muxel, S.M.; da Silveira Cruz-Machado, S.; Marçola, M.; Carvalho-Sousa, C.E.; Cecon, E.; Ferreira, Z.S.; Markus, R.P. Dual Effect of Catecholamines and Corticosterone Crosstalk on Pineal Gland Melatonin Synthesis. Neuroendocrinology 2017, 104, 126-134. [CrossRef] [PubMed]

58. Koga, M.M.; Bizzarro, B.; Sa-Nunes, A.; Rios, F.J.O.; Jancar, S. Activation of PAF-receptor induces regulatory dendritic cells through PGE2 and IL-10. Prostaglandins Leukot. Essent. Fat. Acids 2013, 89, 319-326. [CrossRef] [PubMed]

(C) 2018 by the authors. Licensee MDPI, Basel, Switzerland. This article is an open access article distributed under the terms and conditions of the Creative Commons Attribution (CC BY) license (http:/ / creativecommons.org/licenses/by/4.0/). 